\title{
Seksualność kobieca w Pięćdziesięciu twarzach Greya. Powieściowa fikcja soft-porno czy kulturowe przesunięcie?
}

\section{KEYWORDS}

femininity, sexuality, gender, Fifty Shades of Grey, fiction, Michel Foucault's theory of power, superwoman myth, representation.

\begin{abstract}
Gromkowska-Melosik Agnieszka, Seksualność kobieca w "Pięćdziesięciu twarzach Greya". Powieściowa fikcja soft porno czy kulturowe przesunięcie? [Woman's Sexuality in "Fifty Shades of Grey". Romance Novel Soft-Porn or Cultural Shift?]. Kultura - Społeczeństwo - Edukacja nr 2(6) 2014, Poznań 2014, pp. 23-37, Adam Mickiewicz University Press. ISBN 978-83-232-2869-1. ISSN 2300-0422
\end{abstract}

\begin{abstract}
The purpose of my text is an attempt to define the context of the global fascination of super-bestseller, the book Fifty Shades of Grey - regardless of the fact that literary critics agreed that this is a novel very poor in every aspect. What makes this erotic-romantic story so exceptional, among others, to the extent that it meets with a huge "cultural vindictiveness", entering into public discourse invasively, while hundreds of others good or bad books are ignored?

The main context of interest/fascination with the book Fifty Shades of Grey, in my opinion, is associated with putting again - and doing it radically - question about the permitted forms of female sexuality. Here we are dealing with a sudden shift - by the author - the debate in this area "a few miles ahead" and cancellation of several important tenets, including the dogma of women as innocent virgin, the dogma of women as mothers and wives but also feminist dogma of women socially and sexually liberated from the domination of men.
\end{abstract}

Współczesna rzeczywistość kulturowa przypomina mozaikę - z każdą dekadą coraz bardziej nieuporządkowaną. Do niedawna jeszcze jasne granice i podziały kulturowe rozpraszają się $\mathrm{w}$ tysiące możliwości, a kolejne (zwykle preparowane) ideały i ideologie są konsumowane przez mass media i natychmiast komercjalizowane, co definitywnie kwestionuje ich nośność. To, co makro, splata się z tym, co mikro, to, co ważne, $\mathrm{z}$ tym, co nieważne - do punktu, w którym nie można stwier- 
dzić już, co jest nieważne, a co ważne. Ludzie przeskakują od monotonii do adrenaliny i szukają "fascynujących fascynacji”". Zawsze interesowało mnie, dlaczego w potoku milionów propozycji (pop)kulturowych, pomysłów (i nieprawdopodobnych wymysłów), niektóre nagle nabierają charakteru „olśnienia”, stają się gwiazdą typu supernowa, ogniskując w sposób niezwykle intensywny energię intelektualną i emocje milionów (i odchodząc szybko w zapomnienie; paradoks - kulturowa supernowa może być zdmuchnięta jak świeczka kolejnym fascynującym gadżetem kulturowym). Skąd się wzięła nieprawdopodobna fascynacja tamagotchi, kiedy to miliony ludzi na całym świecie opiekowały się (absurdalnie) japońskim elektronicznym zwierzątkiem niczym własnym dzieckiem? Jakie było źródło nieokiełznanej, wręcz globalnej euforii wokół niezrozumiałej piosenki Gangnam Style koreańskiego wokalisty PSY? Co jest źródłem zaangażowania milionów fanów w wyścigi Formuły 1, gdzie skrajnie skomercjalizowane zespoły wystawiają do walki na śmierć i życie kierowców pędzących po torze z szybkością dochodzącą do ponad $300 \mathrm{~km}$ na godzinę?

Nic się nie dzieje bez przyczyny. Każdy tekst kulturowy, który jest źródłem powszechnej popularności i fascynacji, uosabia pewne tendencje, krystalizuje pewne niepokoje, stanowi wyraz przesunięcia pewnych granic kulturowych lub tworzenia nowych. Wybuch supernowej ma zawsze pierwotną iskrę.

Celem mojego tekstu jest próba zdefiniowania kontekstu globalnej fascynacji „superbestsellerem” - książką Pięćdziesiąt twarzy Greya, niezależnie od faktu, iż krytycy literaccy zgodnie uznali, że jest to powieść bardzo słaba pod każdym względem. Co wyróżnia tę erotyczno-romantyczną opowieść spośród innych, do tego stopnia, iż spotyka się ona z ogromnym „zacietrzewieniem kulturowym”, wchodząc inwazyjnie do dyskursu publicznego, podczas gdy setki innych, lepszych lub gorszych książek, jest ignorowanych?

Z mojej perspektywy główny kontekst zainteresowania/fascynacji książką Pięćdziesiąt twarzy Greya związany jest z postawieniem ponownie, i to w sposób radykalny, pytania o dozwolone formy seksualności kobiecej. Mamy tutaj bowiem do czynienia $\mathrm{z}$ nagłym przesunięciem - przez autorkę - debaty $\mathrm{w}$ tym zakresie „o kilka kilometrów do przodu” i unieważnieniem kilku ważnych dogmatów, w tym dogmatu kobiety jako niewinnej dziewicy, dogmatu kobiety jako matki i żony, ale także i feministycznego dogmatu kobiety społecznie i seksualnie wyzwolonej spod panowania mężczyzn.

\footnotetext{
${ }^{1} \mathrm{Na}$ temat dominującej współcześnie obawy przed monotonnym życiem oraz spadku znaczenia ideologii w konstruowaniu tożsamości zob. Melosik, 2013: 158-169 oraz 163-164.
} 
Wróćmy na chwilę do przeszłości. Oto wiek dziewiętnasty - epoka wiktoriańska, w której „przyzwoita dziewczyna ma głowę, dwoje rąk i nic więcej”2. Kodeks dobrych manier zakazywał dziewczętom oglądania się nago, nawet w lustrze wody. Produkowano wówczas specjalne proszki do mącenia wody, „aby nie narażać poczucia wstydliwości”. Niemalże do końca dziewiętnastego wieku posiadanie luster w miejscach, gdzie można by ujrzeć własną nagość, było uważane za nieprzyzwoite (Corbin, 1999: 445) (w podręczniku dla studentów medycyny z tamtego okresu możemy zobaczyć ilustrację pokazującą dozwolony sposób badania ginekologicznego, na której pacjentka jest całkowicie ubrana, a lekarz dokonujący diagnozy odwraca wzrok od własnych rąk, które dokonują eksploracji „grzesznych” okolic ciała $^{3}$ ). Rodzice, a w szczególności matki, nie szczędzili wysiłków, aby nie dawać córkom dostępu do rzeczywistości, którą dystyngowane klasy spostrzegały jako „seksualnie zanieczyszczoną”. Seksualność zdawała się przy tym „czaić” wszędzie i zakładano, że najprostsze przedmioty mogą wywoływać niemoralne skojarzenia. Stąd na przykład osłaniano materiałem (przywołujące, jak twierdzono, skojarzenia seksualne) nogi pianina i zakazywano nakładania różu na policzki młodym dziewczętom, gdyż mógł on się kojarzyć z wypiekami spowodowanymi „niezdrowym pobudzeniem" (Rugoff, 1971: 60).

Zgodnie z dominującą ideologią, kobietę w epoce wiktoriańskiej uważano za istotę niemalże pozbawioną potrzeb seksualnych i seksualnej wrażliwości, co postrzegano zarówno za normalne i naturalne, jak i społecznie oraz moralnie pożądane (Vicinus, 1972: ix). W tym kontekście można zauważyć, że wzniosłe wyobrażenia Wiktorian o cnocie, która opiera się realnie istniejącym pokusom, pozostawały w przypadku kobiet - jak pisze Martha Vicinus - w sferze teorii (bowiem, dodam, skutecznie robiono wszystko, aby młodym kobietom stworzyć rzeczywistość bez pokus). Odpowiadały one natomiast na oczekiwania wiktoriańskich mężczyzn, szukających idealnej małżonki, która byłaby uosobieniem całkowitej seksualnej niewinności (Vicinus, 1972: ix) i współżycie małżeńskie traktowała nie jako „zmysłową gratyfikację, ale jako dowód uczuć męża” (Krafft-Ebing, 1996: 14).

Ten wiktoriański wariant kobiecości i seksualności kobiecej nadal funkcjonuje w tle - dziś już nieco odległym - szczególnie w kontekście religijnym, choć nie tylko. Wielu mężczyzn nadal jest zafascynowanych dziewictwem kobiet i poszukuje związków z kobietami seksualnie niedoświadczonymi lub wręcz represjonującymi

\footnotetext{
${ }^{2}$ Hasło: Kobiety powinny poznać swoje ciało, w: Kronika Kobiet, red. M.B. Michalik, M. Żmigrodzka, Warszawa 1993, s. 397.

${ }^{3}$ Rycina „Touching the Female Erect”, zob. Maygrier, 1834: 72.
} 
swoje potrzeby seksualne. Książka E.L. James Pięćdziesiąt twarzy Greya absolutnie u podstaw kwestionuje model seksualności kobiecej, który został wyżej opisany.

W okresie ostatnich dekad pojawił się nowy model seksualności kobiecej. Zbyszko Melosik pisze nawet o wybuchu kobiecej seksualności (Melosik, 2002: 49). Warto przytoczyć rozważania tegoż autora, które dobrze ilustrują tę tendencję. Opisywane przez niego „nowe kobiety”, „orientując się głównie na sukces życiowy, przyjmują «chłodną» $\mathrm{i}$ «opanowaną» (...) tożsamość. Używają «zimnych» strategii emocjonalnych, które pozwalają «dobrze bronić się przed zranieniem». Jednocześnie próbują kierować emocjami mężczyzn” (Melosik, 2002: 53)4. Z. Melosik przywołuje poglądy Nancy Colbert Friday, która podważa mit, iż „tylko mężczyźni potrafią oddzielić seks od uczuć; kobiety zaś mogą cieszyć się seksem tylko wtedy, gdy jest on im dany w kontekście trwałego uczuciowego związku" (Friday, 1994: 81).

Tenże autor powołuje się także na Christophera Lascha, który twierdzi, iż współczesne, wyzwolone kobiety „propagują ideę «zimnego seksu», który polega na «mechanicznym odgrywaniu ról» oraz zniesieniu «romantycznych iluzji wokół seksu»” (Melosik, 2002: 53). Melosik pisze dalej, iż „kobieta taka dąży do «optymalnego zaspokojenia» - bez problemów emocjonalnych (uprawianie z kimś seksu nie oznacza, że trzeba tego kogoś kochać, i nie ma to nic wspólnego z tradycyjnym wizerunkiem «kobiety upadłej»). Dla takiej kobiety seksualność i rozkosz przestają być obciążone wstydem” (Melosik, 2002: 53). Na zakończenie raz jeszcze przytoczę dłuższy fragment z książki Z. Melosika: „coraz więc częściej - zarówno w rzeczywistości, jak i (przede wszystkim) umysłach przerażonych mężczyzn - pojawia się zarysowany przez Ch. Lascha obraz «seksualnie żarłocznej kobiety», która staje się źródłem pełnej przerażenia fascynacji. Jej nienasycenie kwestionuje męskość każdego, kto «wpadnie w jej ręce». Postać taka, występująca w przeszłości jedynie w przekazach stricte pornograficznych, dziś staje się coraz częściej bohaterką przekazów kultury popularnej, tego typu kobieta staje się często kobietą "fatalną», uwodzi, wykorzystuje i porzuca, a także poniża, upokarza i ośmiesza" (Melosik, 2002: 57).

Trudno dostrzec powyższy model w książce E.L. James. Mam wrażenie, że główna bohaterka wyzwala się zarówno od schematów wiktoriańskich, jak i feministycznej wersji emancypacji seksualnej. W radykalnym, postmodernistycznym geście unieważnia dawne antynomie, zdając się twierdzić: kobieta może być seksu-

\footnotetext{
${ }^{4}$ Wewnętrzny cytat pochodzi z: A.R. Hichschild, The Commercial Spirit of Intimate Life and the Abduction of Feminism; Signs from Women's Advice Books, „Theory, Culture, and Society” 1991, vol. 11.
} 
alnie taka, jaka chce. Wszystko jest możliwie i nie ma podstaw, aby cokolwiek wartościować.

Przed podjęciem analiz seksualności kobiecej w książce E.L. James, warto stwierdzić, że w świecie, w którym występuje zanik czytelnictwa, Pięćdziesiąt twarzy Greya (tytuł oryginalny: Fifty Shades of Grey) sprzedała się w ponad stu milionach egzemplarzy i została przetłumaczona na ponad pięćdziesiąt języków. Znalazła się na liście bestsellerów, przebijając sukces takich powieści, jak Kod Leonarda da Vinci Dana Browna czy Harry Potter Joan Rowling. W marcu 2012 znalazła się na trzecim miejscu najlepiej sprzedających się książek w historii portalu Amazon. To jednak, co zdecydowało o ogromnym sukcesie serii, czyli postawienie w radykalny sposób kwestii seksualności kobiecej, przyniosło również pod jej adresem liczne oskarżenia o promowanie przemocy i pornografii, sprzeniewierzanie się ideałom emancypacji kobiet i feminizmu oraz destruktywny wpływ na socjalizację młodego pokolenia. W tym kontekście twierdzono, że powieść ta może przyczyniać się kreowania podległej/uległej roli kobiety w relacjach o charakterze seksualnym, przedstawiając ją jako obiekt seksualny poddający się fantazjom mężczyzny aż do przemocy i upokorzenia włącznie. Uważa się również, że „pod płaszczykiem romansu i erotyzmu” powoduje ona „normalizację i glamuryzację przemocy wobec kobiet" (Bonomi [et al.], 2014: 722).

Seria składa się z trzech tomów, zatytułowanych: Pięćdziesiąt twarzy Greya, Ciemniejsza strona Greya i Nowe oblicze Greya. Jej autorką jest E.L. James (prawdziwe nazwisko - Erika Mitchell), była pracowniczka telewizji, absolwentka historii, pięćdziesięciodwuletnia matka dwojga synów (w 2012 roku amerykański tygodnik społeczno-polityczny „Time” uznał ją z jedną z „najbardziej wpływowych ludzi na świecie”, obok takich postaci, jak Barack Obama, Hillary Clinton czy Adele i Rihanna ${ }^{5}$ ).

Głównymi bohaterami Pięćdziesięciu twarzy Greya są: Anastasia Steele, 21-letnia absolwentka filologii angielskiej na Washington State University, i Christian Grey, 27-letni multimilioner, właściciel korporacji Grey Enterprises Holdings INC w Seattle. Łączy ich namiętny romans w stylu BDSM (akronim słów: bond, discipline, sado-maso, oznaczający praktyki typu: wiązanie, dyscyplinowanie, sadomasochizm, opierające się na dominacji i podporządkowaniu), w którym mężczyzna pełni rolę dominującą, a kobieta podporządkowaną. To powieść o dwudziestokil-

\footnotetext{
${ }^{5}$ B. Luscombe, The World's 100 Most Influential People: 2012, „Time”, 18.04.2012, wersja internetowa czasopisma: http://content.time.com/time/specials/packages/article/0,28804,2111975_2111976_2112140, 00.html (dostęp: 15.06.2014 r.).
} 
kulatkach z pokolenia wychowanego $\mathrm{w}$ neoliberalnej wolności (włączając $\mathrm{w}$ to również wolność w sferze seksualnej), które nie potrzebuje tradycyjnych więzi i zaangażowania, a jednocześnie panicznie poszukuje takich form relacji, które dawałyby choć na chwilę poczucie bezwzględnej jedności i wyłączności (nawet jeśli z perspektywy tradycyjnej moralności uznane byłyby one za pornograficzno-patologiczne). Książka jest zaliczana do nowego gatunku dla kobiet: romansu typu soft-porno.

Z perspektywy postawionego na samym wstępie tego artykułu problemu gwałtownego wybuchu popularności pewnych tekstów lub gadżetów kulturowych, główne pytanie dotyczące bezprecedensowego sukcesu trylogii można sformułować w sposób następujący: dlaczego miliony kobiet $\mathrm{z}$ różnych warstw i grup społecznych, kobiet zainteresowanych dotychczas głównie Harlequinami i romantycznymi powieściami, stały się konsumentkami nowego gatunku literatury określanej mianem soft-porno? Krytycy książki i moraliści wyrażają w tym kontekście swój zdecydowany niepokój, który odzwierciedlony jest w pytaniu typu: jakie problemy seksualne i emocjonalne mają kobiety, które czytają książkę E.L. James? (Warto dodać, że książkę tę pogardliwie określa się mianem „soft-porno dla mamusiek”, choć jej czytelniczkami są kobiety w różnym wieku i o różnym wykształceniu). Nie ulega wątpliwości, że w przeszłości to głównie chłopcy i mężczyźni byli monopolistami w zakresie konsumpcji przekazów o charakterze pornograficznym, przy czym niekiedy uważano je za naturalny i nieunikniony element socjalizacji w męskość (por. Kimmel, 2008). Z perspektywy tradycyjnych standardów moralnych i kulturowych, kobieta jako konsumentka pornografii jest zjawiskiem wręcz kuriozalnym.

Sukces książki można też analizować w odniesieniu do „kultury skoku adrenaliny"; w dobie emancypacji kobiet zjawisko to nie dotyczy już tylko mężczyzn, ale również i kobiet. W rzeczywistości, w której mass media przekonują przeciętnych mężczyznę i kobietę, że ich życie (w tym seksualne) jest nudne, szare i pozbawione atrakcji, lektura tekstu o „perwersyjnej seksualności” i o związku Uległej i Pana staje się być może dla części czytelników możliwością doświadczenia nieznanych dotąd i niedostępnych im na co dzień emocji - choćby za pośrednictwem fikcyjnych bohaterów.

6 J. Goudreau, Will Fifty Shades Of Grey Make 'Mommy Porn' The Next Big Thing?, „Forbes”, 19.03.2012; wersja internetowa czasopisma: http://www.forbes.com/sites/jennagoudreau/2012/03/19/willfifty-shades-of-grey-make-mommy-porn-the-next-big-thing/ (dostęp: 15.06.2014 r.). 
Książka wzbudza ogromne kontrowersje. Z jednej strony, znalazła się na liście stu najczęściej wypożyczanych w Stanach Zjednoczonych książek, z drugiej - kilkanaście bibliotek wycofało ją z księgozbioru jako „zawierającą treści o charakterze pornograficznym" ". Autorytety ze świata nauki, wypowiadając się w mediach na jej temat, mają rozbieżne opinie - znajdują się wśród nich i tacy, którzy uważają, że to rodzaj psychologicznego poradnika ratującego rozpadające się związki, i tacy, którzy ostrzegają przed zachęcaniem do niebezpiecznej dla zdrowia psychicznego i fizycznego perwersji.

Pięćdziesiąt twarzy Greya w sposób oczywisty nawiązuje do powieści gotyckiej - powstałej na przełomie XVIII i XIX wieku jako odmiana powieści romantycznej, mrocznej, groźnej i tajemniczej, skoncentrowanej na ciemnej stronie osobowości bohatera. Była ona antidotum na rozwój powieści mieszczańskiej o charakterze moralizatorskim i dydaktycznym. Istotą powieści gotyckiej było wywołanie nastroju grozy poprzez opisywanie sytuacji niejednoznacznych, pełnych niepokoju, związanych ze „skrępowaniem, przymusem, znalezieniem się w pułapce (...), pełnych ekstremalnych gróźb i izolacji, zarówno fizycznej, jak i psychologicznej”. Centralnymi postaciami klasycznej powieści gotyckiej są: młoda dziewczyna, zwykle dziewica, wrażliwa i podatna na zranienie, oraz mężczyzna niosący w sobie przekleństwo, potrafiący łamać normy społeczne i tabu. To powieść pełna „seksualnego pożądania, przyjemności, władzy i bólu”, w której do głosu dochodzi dyskurs „Zabronionej” seksualności: „nieprawej, transgresywnej (...), perwersyjnej, obsesyjnej, voyerystycznej i pełnej przemocy”. Te wszystkie komponenty można odnaleźć w książce E.L. James, która, powtórzę raz jeszcze, unieważnia dawne, tradycyjne propozycje w zakresie seksualności kobiecej.

W trylogii o Christianie Greyu można odnaleźć też toposy baśni o Kopciuszku - przeciętnej dziewczynie o nierzucającej się w oczy urodzie udaje się zauroczyć Księcia, który od pierwszego wejrzenia nie może o niej przestać myśleć. Obsypuje ją kosztownymi prezentami i przenosi do świata luksusu. Jest też nawiązanie do baśni o Śpiącej Królewnie - 21-letnia dziewica, która nigdy nie doświadczyła przyjemności seksualnej i nigdy o niej nie myślała, pod pierwszym spojrzeniem Christiana Greya zostaje natychmiast „przebudzona”, tak, iż w sposób natychmiastowy

${ }^{7}$ T. Lush, Fifty Shades Of Grey' Book Now Banned By Libraries In 3 States, „Huffington Post”, 5.09.2012; strona internetowa czasopisma: http://www.huffingtonpost.com/2012/05/09/book-bannedfifty-shades-of-grey_n_1503949.html (dostęp: 15.06.2014 r.).

${ }^{8}$ J. Bowen, The Gothic. The Novel 1780-1832, artykuł on-line dostępny poprzez British Library: http://www.bl.uk/romantics-and-victorians/articles/gothic-motifs (dostęp: 15.06.2014 r.). 
i instynktowny staje się doskonałą kochanką. W końcu, najbliższe tej powieści jest jej odczytanie w nawiązaniu do Pięknej i Bestii (choć w tym przypadku Bestia jest też piękny, za to jego „bestialstwo” przejawia się w relacjach o charakterze BDSM). Jednak czuła i delikatna, uległa, cnotliwa i wrażliwa Anastasia potrafi odmienić serce i upodobania mężczyzny (w ostatniej części trylogii - Nowe oblicze Greya tytułowy bohater staje się przykładnym narzeczonym, a następnie mężem). To także kolejne odczytanie archetypu superwoman - kobiety posiadającej nadprzyrodzoną moc zmieniania mężczyzn, nawet jeśli dzieje się to wbrew prawu pierwszych połączeń (Christian został uwiedziony w wieku piętnastu lat przez koleżankę swojej matki o upodobaniach BDSM).

Konstrukcja głównych postaci odwołuje się do binarnego schematu: młoda, niedoświadczona (także seksualnie) absolwentka filologii angielskiej, żyjąca bardziej w świecie swoich literackich fascynacji niż w amerykańskiej rzeczywistości, i multimilioner, mający za sobą kilkanaście (raczej mało niewinnych) związków seksualnych z kobietami, sprawujący władzę i kontrolę. On aktywny, ona pasywna, on dominujący, ona uległa, on zdaje się być swoim intelektem, ona - swoim ciałem. To odwieczna antynomia: kobiety jako Natury vs mężczyzny jako Kultury9 Nie bez powodu targaną obawami i strachem Anastasię Christian uspakaja słowami: „Musisz uwolnić swój umysł i wsłuchać się w swoje ciało”.

Książka bez wątpienia wpisuje się w dyskusję pomiędzy zwolennikami tezy o kryzysie męskości a teoretykami piszącymi o zagubieniu kobiet w wolności, o tyranii wyborów, o postfeminizmie i niepokojach wokół emancypacji.

Postać Christiana może być odczytana jako odpowiedź na kryzys męskości mężczyzna, pełen archetypowej męskości, jest władcą ujarzmiającym i podbijającym kobietę. Bohater powieści to uosobienie władzy i kontroli w każdym aspekcie, ale to też mężczyzna piękny i zniewalający poprzez swoją archetypową, brutalną i kontrolującą męskość. To książka napisana przez kobietę, ale główna bohaterka jest tu obiektem pożądania, obiektem seksualnym, pełnym magnetyzmu; niemniej jednak, jest ona też całkowicie podporządkowana mężczyźnie, wciela się - można by powiedzieć: wbrew sobie - w rolę uległej i jemu tylko oddanej. Co o tym decyduje?

Christian Grey jest być może uosobieniem fantazji milionów kobiet - jego postać to powrót do archetypowego mężczyzny (bliższemu „mężczyźnie Marlboro”), który sprawuje kontrolę nad podporządkowaną sobie kobietą - karze ją i nagradza

\footnotetext{
${ }^{9} \mathrm{Na}$ temat typowej dla kultury Zachodu identyfikacji kobiety z Naturą, a mężczyzny z Kulturą zob. Gromkowska, 2002: 47.
} 
zależnie od swoich potrzeb i zachcianek. Ale jest też czuły i troskliwy, empatyczny i przewidujący - zawsze krok przed nią. Reprezentuje bez wątpienia kulturę: gra na fortepianie, zna literaturę, odebrał doskonałe wykształcenie, jest - jak powiedzieliby Brytyjczycy - well rounded. Jest gentelmanem, który troszczy się o swoją kochankę i spełnia jej każde marzenie w sposób niemalże natychmiastowy. To mężczyzna z wyobraźnią i pieniędzmi. Współczesny książę.

Książka wzbudziła kontrowersje wokół kwestii emancypacji kobiet, ich prawa do równości i wolności oraz do kierowania własnym życiem. Ponownie postawiła pytanie o kryzys feminizmu. Relacje między głównymi bohaterami - Christianem Greyem i Anastasią Steel - to absolutne sprzeniewierzenie się ideom feminizmu. Powtórzę raz jeszcze: główna bohaterka to inteligentna, wykształcona na dobrym uniwersytecie, samoświadoma, zarabiająca na siebie amerykańska dziewczyna, która wchodzi w relacje z mężczyzną czyniącym z niej własną „niewolnicę”, skazaną na jego trudne do przewidzenia zmiany nastroju.

Skonstruowana przez E.L. James w Pięćdziesiąt twarzy Greya reprezentacja kobiecości w swoisty sposób odzwierciedla kulturowe wartości i niepokoje rzeczywistości, w której żyjemy, i/lub społeczeństwa (por. Hall, 1997). Trzeba przy tym podkreślić, iż reprezentacje „stanowią «schematy interpretacji», szeroko dostępne, uzyskane poprzez doświadczenie struktury służące dla organizowania i nadawania znaczenia codziennemu życiu. Schematy (...) reprezentują społeczne formy lub struktury naszego życia (...) Schematy negocjują indywidualną biografię i interpersonalne relacje, odzwierciedlając i potwierdzając kulturowo propagowane sposoby pojmowania (...) codziennego doświadczenia” (Holstein, Gubrium, 1994: 267). Niekiedy przy tym jedna $z$ reprezentacji uzyskuje status „chwilowo dominujący” - wówczas większość osób podejmuje wszelkie możliwe starania, aby się w nią „wcielić”. Wkrótce jednak staje się ona „przestarzała” i zostaje porzucona na rzecz nowego (pojawiającego się zwykle w mediach), atrakcyjnego wzorca.

Można więc postawić pytanie, czy miliony kobiet, nawet jeśli zafascynowane są książką i zawartymi w niej formami seksualności kobiecej, w jakikolwiek sposób zaangażują się w praktyki typu sadomasochistycznego? Moim zdaniem, książka o Christianie Greyu prowokuje raczej grę wyobraźni i nie sądzę, aby eksponowane w niej formy seksualności kobiecej na trwałe zmieniły rzeczywistość społeczno-kulturową w tym zakresie. Przesunięcie granic seksualności kobiecej pozostanie w sferze literackiej fikcji.

Można zauważyć, że reprezentacja seksualności kobiecej widoczna w Pięćdziesięciu twarzach Greya potwierdza tę wersję kobiecości, w której redukowana jest 
ona do obiektu seksualnego. Podkreślając władzę reprezentacji, Ben Agger twierdzi, iż w społeczeństwie, w którym kobiety są przedstawiane jako obiekty seksualne, część kobiet reprodukuje takie właśnie zachowania. Odpowiadają one w ten sposób na reprezentacje wytworzone przez androcentryczną kulturę. „Nie sugeruję - pisze Agger - że kobiety mechanicznie przyjmują [narzucone im] role (...), chociaż niektóre z nich tak właśnie robią. Myślę raczej o tym, że reprezentacja pomaga tworzyć totalną kulturę, w ramach której zarówno mężczyźni, jak i kobiety pojmują samych siebie i swoje tożsamości w ramach ustanowionych i ograniczających koncepcji. W praktyce młode kobiety i mężczyźni, którzy konsumują kulturę masową, zamykającą ich $\mathrm{w}(. .$.$) hierarchicznych stosunkach społecznych, postrzegają repre-$ zentacje jako rzeczywistość, nawet jeśli będziemy siebie przekonywać, że życia wykreślone na ekranie (...) są jedynie symulacjami, a ludzie mogą odrzucić wzory przypisane im przez producentów z Hollywoodu. Napór kultury jest tak przemożny, że nie można go zakwestionować poprzez pojedyncze, heroiczne gesty nieposłuszeństwa lub oporu. Niewiele kobiet (...) wyzwala się od reprezentacji, w których dowiaduje się, co oznacza być kobietą - upiększać się dla mężczyzn, żyć dla mężczyzn, aspirować do założenia małżeństwa i posiadania dzieci, postrzegać inne kobiety w kategoriach konkurencji etc." (Agger, 1992: 124).

Powtórzę raz jeszcze, że największe kontrowersje wywołało ukazanie w książce seksualności typu BDSM, dodatkowo w sposób zaprzeczający dotychczasowej stereotypowej wiedzy: jako seksu „bezpiecznego, a nie zagrażającego, psychologicznie zdrowego, a nie będącego wyrazem zaburzeń, aktywnie wybranego, a nie będącego rezultatem nienormalnych popędów, kontrolowanego, a nie opartego na przemocy, dokonanego za obopólną zgodą, a nie represywnego" (Ritchie, Barker, 2005: 228).

Po sukcesie książki, w Internecie rozgorzała dyskusja na temat praktyk typu BDSM, a blogi poświęcone tej tematyce zyskały na popularności. Dla części komentatorów trendu zainteresowania praktykami BDSM szczególnie niepokojąca jest towarzysząca mu naturalizacja dyskursu, jak się twierdzi, o charakterze przemocowym, w który wpisane są nadużycie i ból (por. Bonobi, Altenburger, Walton, 2013). W ten sposób, aby odwołać się do Michela Foucaulta, dyskursy wiedzy i władzy podlegają transformacji. Zmienia się więc to, kto jest podmiotem dyskursu (np. kto jest zdrowy, a kto jest szaleńcem, kto mieści się w normie seksualnej, a kto jest perwersyjny), a wraz z tym zmianie podlega pojęcie normy - to, co mieści się w normie, jest zależne od dyskursu - w tym przypadku pochodzenia medialnego. Zmianie ulega również $\mathrm{w}$ związku z tym sposób traktowania jednostek uznanych dotąd za „odchylonych od normy” (por. Foucault, 1993; 2000). 
Odwołując się do Michela Foucaulta, trzeba zauważyć, że gdyby władza, którą posiada Christian Grey nad Anastasią Steele, miała charakter wyłącznie represywny, wówczas nie byłaby efektywna. „To, co czyni ją akceptowalną, to fakt, że nie oddziałuje ona (...) jako siła, która zabrania czynienia rzeczy, ale również zaprzecza [traverses] i wytwarza rzeczy, indukuje przyjemności, tworzy wiedzę, wytwarza dyskurs; to przez nią jednostki stają się podmiotami - poprzez mechanizmy kształtowania się podmiotowości, podporządkowania się podmiotowości i poprzez podmiotowość” (Ricken, 2009: 551). Władza Christiana Greya nad tożsamością Anastasii Steele jest władzą w ujęciu Michela Foucaulta - jest nie tylko siłą "prohibicyjną”, ale też siłą „nie egzekwowaną odgórnie, tylko szeroko rozprzestrzenioną; nie czysto polityczną czy ekonomiczną, ale rozproszoną w wielości form: od finezyjnie dostrojonej dyscypliny cielesnych ruchów do najszerszych reguł formułowania prawdziwych stwierdzeń"10. Tak rozumiana władza jest wpisana w relacje międzyludzkie, także te o charakterze seksualnym. Można jej się poddać, ale można również jej zaprzeczyć, przeciwstawiając się jej w akcie nieposłuszeństwa, oporu, wyjścia poza dopuszczalne granice dyskursu. A zatem jest ona „zbiorem zmieniających się stale relacji, ruchomą siecią walki nieustannie strukturującej pole akcji”"11.

Anastazja, która pokonuje własne granice (strachu i seksualności), posiada wolność wyboru. Jednak - zgodnie z ideą foucaultowskiej wolności - zawsze jest to wybór dokonywany w polu władzy. Trzeba przy tym zauważyć, że w książce, podobnie jak u Foucaulta, kategoria władzy nie jest jednoznaczna, nie jest również tożsama $z$ represją i narzucaniem. Nie oznacza wyłącznie władzy zewnętrznej wobec podmiotu - często władza nad podmiotem jest uwewnętrzniona przez sam podmiot. Władza jest więc zawsze rozproszona. Foucault pisze w Historii seksualności, iż: „Władza jest wszędzie - nie dlatego, że wszystko obejmuje, ale dlatego, że zewsząd się wyłania (...). Władza nie jest ani instytucją, ani strukturą, ani czyjąkolwiek potęgą; jest nazwą użyczaną złożonej sytuacji strategicznej w danym społeczeństwie" (Foucault, 2000: 84). Władza, którą posiada Christian Grey, przyczynia się do tworzenia wiedzy oraz do kształtowania tożsamości Anastasii. Bohaterowie nie mogą lekceważyć władzy, ponieważ ona konstytuuje ich tożsamość i podmiotowość. Z jednej strony ma ona charakter represywny, normalizujący, wykluczający, ale z drugiej... jest źródłem przyjemności (Foucault, 1993: 233). Jednak gra, która

${ }^{10}$ J.E. McGuire, Hermeneutyka jaźni: Foucault o subiektywizacji i krytyce genealogicznej, „Nowa Krytyka. Czasopismo Filozoficzne”, 20.01.2008, http://nowakrytyka.pl/spip.php?article266 (dostęp: 15.06. 2014 r.).

${ }^{11}$ Ibidem. 
toczy się między podmiotami dyskursu, nie buduje - jak ujmuje to Foucault, pisząc o dyskursie seksualnym - „wokół płci i ciał nieprzekraczalnych granic, ale trwałe spirale władzy i rozkoszy" (Foucault, 2000: 47).

Dyscyplina, uwewnętrzniona przez Anastasię w sposób dobrowolny, staje się władzą nad jej ciałem: „dostaje się [ono] w tryby maszynerii władzy, która dokonuje rewizji, rozbiera na części i na powrót je składa. (...) Określa ona, w jaki sposób można wpływać na ciała innych - nie tylko żeby wykonywały to, czego się od nich chce, ale też żeby działały tak, jak się chce, przy pomocy z góry określonych technik, z określoną szybkością i wydajnością. Dyscyplina wytwarza tedy ciała podporządkowane i wyćwiczone, ciała «podatne»" (Foucault, 1993: 164).

Opisywane w książce Pięćdziesiąt twarzy Greya praktyki BDSM przyczyniły się do zainteresowania badaczy „wpływem”, jaki może mieć czytanie tej powieści na przejawianie zachowań szkodliwych dla swojego zdrowia. Autorki artykułu Fiction or Not? Fifty Shades is Associated with Health Risks in Adolescent and Young Adult Females - Amy E. Bonomi, Julianna M. Nemeth, Lauren E. Altenburger, Melissa L. Anderson, Anastasia Snyder i Irma Dotto, zaznaczają na jego wstępie, że są pionierkami w badaniach nad związkiem między czytaniem prozy opisującej przemoc wobec kobiet (konkretnie - trylogii o Christianie Greyu) a podejmowaniem zachowań ryzykownych dla zdrowia. Autorki objęły badaniami ponad 700 kobiet w wieku 18-24 lat, studiujących na dużym uniwerystecie amerykańskim. W rezultacie przeprowadzonych badań stwierdziły one, iż „istnieje silna korelacja między ryzykiem zdrowotnym $\mathrm{w}$ życiu kobiet - włączając $\mathrm{w}$ to wiktymizację z użyciem przemocy - a konsumowaniem Pięćdziesięciu twarzy Greya". Nie są jednak w stanie, jak podkreślają, określić wymiaru temporalnego tego związku - nie wiadomo, czy czytanie tej książki przyczynia się do podejmowania zachowań ryzykownych (wchodzenia w przypadkowe związki seksualne, podejmowanie nowych, uważanych za niestandardowe form seksu, upijania się, zaburzeń odżywiania się), czy też czytelniczkami jej są kobiety, które doświadczały już w przeszłości tego typu zachowań (Bonomi [et al.], 2014: 722-723).

Skłaniałabym sie do tej drugiej interpretacji. Osobiście nie wierzę, wbrew powyższej opinii, aby książka E.L. James stała się czymś więcej niż efemerydą, która fascynuje i znika. W żadnym też przypadku Christian Grey i Anastasia Steele nie staną się ikonami kultury popularnej, takimi jak choćby Batman czy James Bond. Powieść Pięćdziesiąt twarzy Greya natrafiła na pewną konfigurację kulturowych niepokojów, które w tym artykule usiłowałam uchwycić. Nie zasługuje ona na uwagę ze względu na swoją wartość literacką - pojęcie soft-porno zapewne najlepiej oddaje jej klimat - a jednak... jej nadzwyczajna popularność oraz niekończące się dyskusje sprowokowały mnie do napisania tego tekstu. 


\section{Literatura}

Agger B. (1992). Culture Studies as Critical Theory. London.

Bonomi A.E., Altenburger L.E., Walton N.L. (2013): „Double Crap!” Abused and Harmed Identity in „Fifty Shades of Grey”. „Journal of Women's Health”, vol. 22, no 9, s. 733-744.

Bonomi A.E., Nemeth J.M., Altenburger L.E., Anderson M.L., Snyder A., Dotto I. (2014). Fiction or Not? Fifty Shades is Associated with Health Risks in Adolescent and Young Adult Females. „Journal of Women's Health", vol. 23, no 9, s. 720-728.

Corbin A. (2009). Kulisy. [W:] Historia życia prywatnego, tom IV. Red. M. Perrot. Wrocław - Warszawa - Kraków, s. 425-643.

Foucault M. (1993). Nadzorować i karać. Narodziny więzienia, przeł. T. Komendant. Warszawa.

Foucault M. (2000). Historia seksualności, przeł. B. Banasiak, T. Komendant, K. Matuszewski. Warszawa.

Friday N. (1994). Kobiety górą, przeł. J. Wildecka. Poznań.

Gromkowska A. (2002). Kobiecość w kulturze globalnej. Rekonstrukcje i reprezentacje. Poznań.

Hall S. (1997). The Work of Representation. [W:] Representation. Cultural Representations and Signifying Practices. Red. S. Hall. London, s. 13-74.

Hichschild A.R. (1991). The Commercial Spirit of Intimate Life and the Abduction of Feminism; Signs from Women's Advice Books. „Theory, Culture, and Society”, vol. 11, s. 1-23.

Holstein J.A., Gubrium J.F. (1994). Phenomenology, Ethnomethodology, and Interpretive Practice. [W:] Handbook of Qualitative Research. Red. N.K. Denizn, Y.S. Lincoln. London, s. 262-272.

Kimmel M. (2008). Guyland. The Perlous World Where Boys Become Men. New York.

Krafft-Ebing R. (1886). Psychopathia Sexualis, with Especial Reference to the Antiphatic Sexual Intinct. A Medico-Forensic Study. New York.

Maygrier J.P. (1834). Midwifery Illustrated. New York.

Melosik Z. (2013), Kultura popularna i tożsamość młodzieży. W niewoli władzy i wolności. Kraków.

Michalik M.B., Żmigrodzka M. red. (1993). Kronika Kobiet. Warszawa.

Ricken N. (2006). The Power of Power - Questions to Michel Foucault. „Educational Philosophy and Theory", vol. 38, no 4, s. 541-560.

Ritchie A., Barker M. (2005). Feminist SM: A Contradiction in Terms or a Way of Challenging Traditional Gendered Dynamics through Sexual Practice? „Lesbian and Gay Pscyhology Review”, vol. 6, no 3, s. 227-239.

Rugoff M. (1971). Prudery and Passion: Sexuality in Victorian America. New York.

Vicinus M. (1972). Introduction. The Perfect Victorian Lady. [W:] „Suffer and Be Still”. Women in the Victorian Age. Bloomington - London, s. vii-xv.

Z. Melosik (2002). Kryzys męskości w kulturze wspótczesnej. Poznań.

Źródła internetowe:

Bowen J., The Gothic. The Novel 1780-1832, http://www.bl.uk/romantics-and-victorians/ articles/gothic-motifs (dostęp: 15.06.2014 r.)

Goudreau J., Will Fifty Shades Of Grey Make 'Mommy Porn' The NextBig Thing?, „Forbes”, 19.03.2012; http://www.forbes.com/sites/jennagoudreau/2012/03/19/will-fifty-shades-of-greymake-mommy-porn-the-next-big-thing (dostęp: 15.06.2014 r.). 
Luscombe B., The World's 100 Most Influential People: 2012, „Time”, 18.04.2012; http://content. time.com/time/specials/packages/article/0,28804,2111975_2111976_2112140,00.html（dostęp: 15.06.2014 r.).

Lush T., Fifty Shades Of Grey' Book Now Banned By Libraries In 3 States, „Huffington Post”, 5.09.2012; http://www.huffingtonpost.com/2012/05/09/book-banned-fifty-shades-of-grey_n_ 1503949.html (dostęp: 15.06.2014 r.).

McGuire J.E., Hermeneutyka jaźni: Foucault o subiektywizacji i krytyce genealogicznej, „Nowa Krytyka. Czasopismo Filozoficzne”, 20.01.2008; http://nowakrytyka.pl/spip.php?article266 (dostęp: 15.06.2014 r.).

\section{Woman's Sexuality in Fifty Shades of Grey. Romance Novel Soft-Porn or Cultural Shift?}

\section{Summary}

Contemporary cultural reality resembles a mosaic - with every decade more and more disordered. Until recently, have clear boundaries and cultural divisions disperse the thousands of possibilities, and another (usually prepared) ideals and ideologies are consumed by the mass media and immediately commercialized, definitely have been lacked of their capacity. This is what the macro is intertwined with what micro; is what is important, no matter with what - to the point where you can not tell already, what is and what is not important. People jump from the monotony of the adrenaline and seek "fascinating fascination". Always I was interested in, why in the creek million proposal (pop) cultural ideas (and improbable gadgets), some suddenly acquire the status of "enlightenment", become a star type of supernova, focusing in a very intense intellectual energy and excitement of millions (and moving away quickly in oblivion; Paradox - cultural supernova can be blown away like a candle by next cultural fascinating gadget). How it came about the incredible fascination tamagotchi, where millions of people around the world cared for (absurdly) Japanese electronic pet like your own child ?; what was the source of unbridled, even global euphoria around the incomprehensible song Gangnam Style Korean singer PSY?; What is the source of the involvement of the millions of fans of racing Formula 1, where extremely commercialized teams set to fight to the death and life of drivers speeding around the racetrack at a speed of up to $300 \mathrm{~km}$ per hour?

Each cultural text, which is the source of universal popularity and fascination embodies certain trends, crystallizes some concerns, and also is an expression of the cultural shift within certain cultural limits or creating new borders. Supernova's explosion has always its original spark.

The purpose of my text is an attempt to define the context of the global fascination of superbestseller, the book Fifty Shades of Grey - regardless of the fact that literary critics agreed that this is a novel very poor in every aspect. What makes this erotic-romantic story so exceptional, among others, to the extent that it meets with a huge "cultural vindictiveness", entering into public discourse invasively, while hundreds of others - good or bad books are ignored?

From my perspective, the main context of interest / fascination with the book Fifty Shades of Grey is associated with putting again - and doing it radically - question about the permitted forms of female sexuality. Here we are dealing with a sudden shift - by the author - the debate in this area 
"a few miles ahead" and cancellation of several important tenets, including the dogma of women as innocent virgin, the dogma of women as mothers and wives but also feminist dogma of women socially and sexually liberated from the domination of men.

I have the impression that femininity model in the book E.L. James Fifty Shades of Grey is released from both the Victorian patterns and feminist version of sexual emancipation. Anastasia Steel, the main heroine, seems to me invalidate - in the radical postmodern gesture - the old antinomies: a woman can be sexually the way she wants. Everything is possible, and there is no reason to do any estimate. 